\title{
Water civilization in Serat Centhini : Ethno-hydraulic perspective
}

\author{
Sahid Teguh Widodo ${ }^{1}$ and Agus Purwantoro ${ }^{2}$ \\ \{1 sahidteguhwidodo@yahoo.co.id.2 ${ }^{2}$ goespoer13@yahoo.co.id\} \\ ${ }^{1}$ Faculty of Cultural Science, Universitas Sebelas Maret, Surakarta, Indonesia \\ ${ }^{2}$ Faculty of Arts And Design, Universitas Sebelas Maret, Surakarta, Indonesia
}

\begin{abstract}
This paper is presented as a research output entitled Water Conservation and Environment based on Javanese ancient manuscripts in the 19th century. The specific purpose of this study is to find out the role of water that characterizes Javanese culture. Javanese people highly value water so that folklore, art, tradition and myth are linked to the existence and management of water. The form of research is descriptive qualitative with text data in the Centhini manuscript of 12 volumes. Data were analyzed using interactive analysis techniques. The results of this study indicate (1) the ethnohydrolic approach is able to unpack the contents of Centhini Fiber (SC) in more depth, (2) water civilization in $\mathrm{SC}$ is displayed indirectly so it needs the right meaning to be able to find out, and (3) there is a lot of data and information which is related water civilization on Java.
\end{abstract}

Keywords: Centhini, civilization, water management, myth

\section{Introduction}

In all parts of the world, there are many forms of civilization and culture that are related to the presence of water [1]. Human knowledge about water is equivalent to its existence on this earth [1]. Water is the guarantor of life itself [2]. The same thing happened in Indonesia, an island nation that has tens of thousands of cultural traditions about water[3]. The discourse of aquatic civilization has almost become the biggest cultural issue in history. On each island there is a large lake, dam, reservoir or situ as a reservoir of water. Lake Aneuklaot in Aceh, Lake Batu Jai in West Nusa Tenggara, Lake Emas in Bengkulu, Lake Bekuan in West Kalimantan, Lake Towuti in South Sulawesi, Lake Ranu Klakah in East Java, and Gajah Mungkur and Kedung Amba Reservoirs in Central Java.Indonesia is a land of water, including in the Central Java Surakarta region [4] and He stated that since the migration of the kingdom (1745 AD) from Kartasura to Surakarta Hadiningrat, the development of civilization in Surakarta was inseparable from efforts to manage the flow along the Bengawan Solo river. Utilization of the Bengawan Solo flow as a transportation lane, trade lane, lane that functions to serve environmental transport with the characteristics of short and medium distance travel with a low average density level. The demographic conditions in the Bengawan Solo water environment have changed rapidly the economic conditions of society, social life and culture. In other words, the regions around Bengawan Solo became prosperous at that time. The 
Surakarta community has experienced relatively rapid changes in life since the construction of irrigation jackets, local tourism objects, and the provision of clean water which are the main pillars of life. [5].

An important source of the birth of water civilization in Old Javanese manuscripts is the Serat Centhini or Suluk Tambangraras by Pakubuwana V in Surakarta. Serat Centhini is written in the genre of traditional Javanese poetry (tembang), and the writing is grouped according to the type of song. The 'time marker' trumpet in Serat Centhini shows it was written in the last period of Old Javanese literature (1814 AD). However, the story in it occurred in 1630-1639 AD, after a dispute between the Kingdom of Mataram and Giri. All historical stories are arranged in the form of traditional Javanese poetry as imaginative works of Javanese literature.

The study of awater civilization in Serat Centhini is very important [6] to be carried out as a hallmark of thousands of years of Javanese cosmology. The description of the cultural setting of aquatic civilization in Javanese mythology has been transformed into a very beautiful story. The results of the search are expected to find the form of aquatic civilization referred to in the Manuscript. Cases related directly or not are displayed and carefully verified so that their implementation can be found. The implementation of this water civilization is described in the journey of Seh Amongraga, Tambangraras, Centhini, and Cebolang.

This study uses an ethnohydrolic approach. Ethnohyrolica is a multi-desipline that combines the hydrological, hydraulics and ethnographic paradigms. Hydrology is the science of water matters[6]. The implementation of hydrology is known as the hydraulics 'the study of water flow efforts'. In its development came the theory of socio-hydrology, an interdisciplinary science that studies water material in a social context. Ethnohydrolica is an interdisciplinary study that studies the influence of culture on various water treatment efforts. That is, water has a close relationship with cultural development. Water is the cultural dimension that drives the birth of civilization. Civilization produces various forms of culture that are able to explain how the values, knowledge, traditions, and world views of a collective or individual of water, how to model and strategy for the use, management and control of water.

\section{Research Method}

This study examines the cultural setting, shape, and implementation of water conservation from the Old Javanese manuscript source, which is Serat Centhini's by Paku Buwana V with an ethnohydrolic approach. Research data sources are 12 volumes of Serat Centhini published by the Yogyakarta Centhini Foundation with different printing presses. Centhini Volume 1 was printed in 1982 by CV Batu Hitam Offset, Volume 2 and 3 by Printing Surya Gading Yogyakarta (1986), volumes 4 and 5 by PT. KR Yogyakarta (1988), Vol. 6 and 7 by PT. Hidayat Yogyakarta (1989), Volumes 8,9,10,11, and 12 by Balai Pustaka in 1990 and 1991).

This study analyzes the conservation of water resources from an ethnohyrolic perspective; it is a study of the process of water conservation based on local wisdom of Javanese culture[7] Research data collected by using content analysis techniques, is a way to analyze the contents of Serat Centhini by identifying the characteristics of each information and giving systematic coding to each part objectively, systematically, and having teoretic references. Empirical facts collected from Serat Centhini utilizing the interactive work of three components, are (1) data reduction, separating important and less important data according to research problems by 
reading the script carefully and accurate, (2) data display, based on data characteristics and study issue, (3) data verification and drafting the conclusions.

\section{Results And Discussion}

\subsection{Ethno hydraulics implementation in Serat Centhini (SC)}

The basic concept of ethnohydrolica relates to language and culture, rules and norms, patterns of behavior and socio-cultural images. Ethnohydrolic approach considers the importance of the quality of an event, event, situation, or situation so that it needs to be handled properly [8]. Culture in ethnohydrolica is understood as the set of knowledge that a person gains in interpreting experiences that produce a behavior [9]. Various variants of thought forms, views, and understanding of the community about water are a cultural process [10] so that the birth of different water civilizations also depends on human perception of the life they live [10].

Ethnohydrolica makes it possible to develop concepts ideally or practically. Various forms of myths and folklore related to 'water' in the SC become interesting as a comparison material (analogy). Plaits of life events experienced by figures of Seh Amongraga, Tambangraras, Cebolang, and Centhini are cultural sub-systems and become life characteristics in Javanese society. A picture of an authentic civilization system that produces culture, namely values, beliefs, knowledge, procedures, and traditional ceremonies. The contents in SC are data and information that have important meaning to explain for hydrological wisdom even though they are still wrapped in imagination, mysticism, and superstition.

Ethno Hydraulics is a multidisciplinary which is used to understand various cultural images of maintaining, managing and preserving water resources so that a culture of water is born[11].

\subsection{Centhini and the nativity of a water civilization}

At least three reasons underlying the selection of SC by Sinuhun Pakubuwana V, which was written in $1814 \mathrm{AD}$ and published by the Yogyakarta Centhini Foundation. In total, Serat Centhini consists of 722 sections, 31,837 verses of poetry, and 3,467 pages of text, and the publication is divided into 12 volumes as sources of clothing. These reasons are: (1) the value of cultural knowledge about "Water Civilization" in SC; (2) Old Javanese manuscripts are still rarely used extensively with in-depth scope of study, and (3) The need to find alternative sources of wisdom and new approaches for improving the quality of environmental management.

Water civilization in Serat Centini as referred to in this study is the cultural identity achieved by humans in the form of intelligence, work, manners, manners and traditions related to water management contained in Serat Centini in Surakarta. The story of the odyssey of Jayengresmi, Jayengsari, and Rancangpati. The three of them were sons of Sunan Giri who had been defeated by Prince Pekik, a messenger from the Kingdom of Mataram. Along the journey of the journey of these three figures, it can be seen the contents of the manuscript relating to environmental management, including water management. 


\begin{tabular}{|c|c|c|c|c|}
\hline No. & Type of Conservation & Form of Conservation & $\begin{array}{l}\text { Centhini } \\
\text { (Volume) }\end{array}$ & Page \\
\hline \multirow[t]{2}{*}{1} & Water environment & Look after water & 1 & $143-144$ \\
\hline & & Make wells & 3 & 306 \\
\hline \multirow[t]{2}{*}{2} & Forest environment & Protect the forest & 3 & 209 \\
\hline & & $\begin{array}{l}\text { Method for cutting down } \\
\text { teak trees }\end{array}$ & & \\
\hline \multirow[t]{4}{*}{3} & Agricultural/garden & Agricultural methods & 7 & $201-215$ \\
\hline & environment & Plant banana trees & 9 & $212-214$ \\
\hline & & earthquakes Work in the & 1 & $142-152$ \\
\hline & & rice-fields & 7 & $\begin{array}{l}203,207,214- \\
215\end{array}$ \\
\hline \multirow[t]{3}{*}{4} & Sky environment & Look after the sky & 5 & $71-78$ \\
\hline & & The nature of comets & 2 & $127-136$ \\
\hline & & The Pleiades and Orion & 8 & $39-40$ \\
\hline \multirow[t]{2}{*}{5} & Animal environment & Take care of animals & 2 & $33-35$ \\
\hline & & Take care of horses & 2 & $35-38$ \\
\hline \multirow[t]{3}{*}{6} & Pranatamangsa & Pranatamangsa & 1 & $182-190$ \\
\hline & & Nature of time & 2 & $33-34$ \\
\hline & & & 3 & $41-50$ \\
\hline
\end{tabular}

\subsection{Sacrality of water in Serat Centhini (SC)}

Centhini is the most complete Old Javanese manuscript (The whole Serat Centhini consists of 722 poems of 31,837 verses, 3,467 pages of manuscripts, and is divided into 12 volumes of books. This is the longest ancient text in history that anyone has written in the world). Based on the process of reading the SC carefully and accurately, it is known that Javanese culture is rooted in an agrarian tradition. For agrarian societies, the existence of water is absolute and cannot be separated. So important is water that gives birth to myths and various sacred folktales.

Table 2. Various water myths in SC

\begin{tabular}{|c|c|c|c|}
\hline Form of Mythos & Description & Figur Involved & Volume: Page \\
\hline $\begin{array}{l}\text { The myth ofJumprit } \\
\text { Praga river }\end{array}$ & $\begin{array}{l}\text { - Water as physical health } \\
\text { - Healing diseases } \\
\text { - The meaning of personal } \\
\text { name }\end{array}$ & Jumprit & $2: 16$ \\
\hline $\begin{array}{l}\text { The myth of Song } \\
\text { Putri cave }\end{array}$ & $\begin{array}{l}\text { - The myth of Guwa Kalak } \\
\text { water } \\
\text { - Disease healing myths } \\
\text { - The cause of human } \\
\text { pralaya } \\
\text { - How to get grace }\end{array}$ & $\begin{array}{l}\text { Seh Amongraga, } \\
\text { Gothak, Gathuk }\end{array}$ & $3: 41,68,77$ \\
\hline $\begin{array}{l}\text { The myth of Redi } \\
\text { (mountain) Semeru }\end{array}$ & $\begin{array}{l}\text { - The holy waters of } \\
\text { Mount Semeru } \\
\text { - The greatness of water in } \\
\text { Wirasaba } \\
\text { - Wirasaba dan Sokayasa }\end{array}$ & $\begin{array}{l}\text { Mas Cebolang, para } \\
\text { santri, wirasaba, Buyut } \\
\text { Danadharma }\end{array}$ & $\begin{array}{l}5: 11,32,39- \\
40\end{array}$ \\
\hline
\end{tabular}

The table above shows that Javanese people always give high appreciation to water. Water and its properties are a source of inspiration in the Javanese personal naming tradition. Names such as Sutirta, Banyuwangi, Warih Tri Kartono, Dewi Toyaningtyas, Bening Punaningtyas, 
and other similar names are evidence of closeness, value, and respect for water. Not infrequently the existence of the element 'water' is accompanied by other natural elements, such as mountains, mega, gemstones, wind, even the names of plants and animals.

Table 3. Artificial waterreservoir in Serat Centhini

\begin{tabular}{|c|c|c|c|c|c|}
\hline Word & Phonetic & Description & $\begin{array}{l}\text { Centhini } \\
\text { (Volume) }\end{array}$ & Page & Verse \\
\hline Sumur & sumUr & $\begin{array}{l}\text { The deep hole contains a water } \\
\text { source }\end{array}$ & 1 & $\begin{array}{l}59 \\
81 \\
143 \\
180\end{array}$ & $\begin{array}{l}33 \\
17-18 \\
27-44 \\
12\end{array}$ \\
\hline Padasan & padasan & Ablution water container & 1 & 180 & 13 \\
\hline Bak & bak & Water container & 1 & 186 & $8-9$ \\
\hline Kolam & $\begin{array}{l}\text { kola } \\
\mathrm{m}\end{array}$ & $\begin{array}{l}\text { Water reservoirs for raising fish } \\
\text { or swimming }\end{array}$ & 1 & 199 & $32-33$ \\
\hline Pangangson & $\mathrm{pa}\rceil \mathrm{a} \prod \mathrm{s} \bigcirc \mathrm{n}$ & A place to take water & 1 & 180 & 12 \\
\hline Jembangan & jəmba!an & Water container & 1 & 180 & 16 \\
\hline Sanggariti & SOMgPriti & Water comes out of the temple & 1 & 214 & 29 \\
\hline
\end{tabular}

\subsection{The message of water civilization in SC}

The story of the journey of Seh Amongraga and Ni Ken Tambangraras followed by a servant named Centhini shows that water has got various names. Water is always called for the necessities of life, worship, myths, and even political means of power. This is proof of how much respect the Javanese people have for water as a "teacher" who always gives selflessly, teaches life completely and comprehensively, gives meaning to every effort that is prosperous, prosperous, and happy for survival. The value of water in Javanese civilization in $\mathrm{SC}$ is as follows [12].

a. Give benefits to others

The story of the wanderings of Prince Rancangkapti and Jayengsari illustrates the existence of a very strategic water. Water that is well managed, utilized and glorified is proven to have brought benefit to humankind in this world. Water that runs clear and healthy will fertilize the soil, grow various types of food plants, vegetables, and abundant fruits that we can use for our lives together. Water teaches us to always try to benefit others, serve the community, and improve their welfare. Don't forget, water quality is a parameter of community conditions.

b. Unity, fairness and justice

Seh Amongraga's advice to Ni Ken Tambangraras states that water has a clean and clear appearance and character. Clean and clear symbolizes the silence of the heart, honesty with justice. The flow of the flow symbolizes the power of unity. How we who live as a nation must work together, united, daya-dinayan, mad-sinamadan, and gotong royong to achieve greater goals.

c. Live a dynamic life

The reunion of Sunan Giri's children was a pleasant moment. At that time Seh Amongraga said that he would continue the journey to find the perfection of life towards Heaven. Seh Amongraga's message to his two younger siblings stated that "water is not always permanent but is changing". That fact teaches us to be dynamic in life, creative and innovative, flexible, adaptable, and not easily discouraged, despite the many bends, rocks, root of trees that can inhibit the flow of water. A dynamic life is an expression of intelligence living life. From the dynamic stomach contained endurance, fighting spirit, training on the rules of the game, 
instinct to win, great spirits and sportsmanship. A progressive dynamic based on honesty and sincerity, so water teaches us.

d. Decisive and courageous leader

Water always flows from a high place to a lower place. This is the style of water leadership that is always in touch and responsible to its subordinates. Water always teaches etiquette of etiquette, wisdom, subtlety of mind, like a flowing life. But if the truth is tainted, the principles and dignity of the nation are torn apart and disturbed, clear water can turn into a flood that has enormous power and destroys all its obstacles and disrupts. Water teaches us to be brave and resolute. And, because of the glory of the nature of water, however, 'he' still leaves fertile humus, returning life to its right path [13].

\section{Conclusion}

Many things can be learned from water. Ethnohydrolica as a branch of science combines two forms of understanding, namely traditional understanding and modern understanding to maintain, manage, and utilize water for shared life. myths and folklore, fairy tales, legends, traditional rites, oral stories, and the natural environment are all combined and applied to form a system that is integrated in efforts to save water and the environment. Patterns, models, strategies, and ways to maintain, manage and use water in each region depend on the understanding, knowledge, awareness, tradition system of the community itself. Therefore, understanding culture in this context is very important because it plays an important role in shaping people's thinking and views.

Research on water civilization is rarely studied. We still know a lot about water research that seems mechanistic. The model offered by ethnohydrolica is different because it wants to "hear" inequality in various sectors. Therefore, it is necessary to research the development of the model, which is implementing an organismic system of preservation, management and utilization of water. Humans, the natural environment, social and cultural environment, are an inseparable unity. Each part is indeed unique and therefore must be studied in its context based on relationships, holistic understanding, roles, and position respectively.

\section{References}

[1] M. Maridi, "Mengangkat Budaya dan Kearifan Lokal dalam Sistem Konservasi Tanah dan Air," Pros. Semin. Nas. Biol., no. 1, pp. 20-39, 2015.

[2] P. Sidauruk, E. R. Pujiindiyati, and S. Satrio, "Subsurface Flow and Surface Water Interactions Quantification in Gunung Kidul Karst Area Using Hydro- Chemical and Stable Isotopes Data Variations," J. Ilm. Apl. Isot. dan Radiasi, vol. 11, no. 1, p. 65, 2016.

[3] E. B. Sasongko, E. Widyastuti, and R. E. Priyono, "Kajian Kualitas Air Dan Penggunaan Sumur Gali Oleh Masyarakat Di Sekitar Sungai Kaliyasa Kabupaten Cilacap," J. Ilmu Lingkung., vol. 12, no. 2, p. 72, 2014.

[4] Riyadi, "Modernisasi Kota Surakarta Awal Abad XX," Fkip Uns, 2009.

[5] M. Dwi, S. Nugroho, and Y. F. La Kahija, "Makna Pemakaian Gelar Kebangsawanan Jawa (Sebuah Interpretative Phenomenological Analysis)," Empati, vol. 5, no. 3, pp. 518-523, 2016.

[6] V. Yevjevich, "Water and Civilization," Water Int., vol. 17, no. 4, pp. 163-171, Jan. 1992.

[7] M. Levin-Keitel, "Managing urban riverscapes: towards a cultural perspective of land and water governance," Water Int., vol. 39, no. 6, pp. 842-857, Sep. 2014.

[8] S. T. Widodo and K. Saddhono, "Petangan tradition in Javanese personal naming practice: An 
ethnoliguistic study," GEMA Online J. Lang. Stud., vol. 12, no. 4, pp. 1165-1177, 2012.

[9] A. Sutisna, "Etnografi Sebagai Penelitian Kualitatif," pp. 1-31, 2016.

[10] D. Hoagland, D. Arnon, D. R. Hoagland, D. I. Arnon, and C. B. Hutchison, "The water-culture method for growing plants without soil / The Water-Culture Method For Growing Plants Without Soil Professor of Plant Nutrition and Chemist in the Experiment Station. 2 Instructor in Truck Crops and Junior Plant Physiologist in the Experi," pp. 1884-1949, 1938.

[11] A. Conker, "Understanding Turkish water nationalism and its role in the historical hydraulic development of Turkey," Natl. Pap., vol. 46, no. 5, pp. 877-891, Sep. 2018.

[12] M. Dan and A. Transformational, "Transformational Thinking: Bahasa Dan Budaya Jawa Sebagai Pondasi Pendidikan," pp. 1-8.

[13] S.T. Widodo and K. Saddhono. "Petangan Tradition In Javanese Personal Naming Practice: An Ethnoliguistic Study." GEMA Online® J. of Lang. Stu. vol. 12 no. 4 pp 1165-1177, 2012 